\title{
HUSBAND'S SUPPORT WITH THE USE OF THE IUD CONTRACEPTION IN THE ACCEPTORS IN THE WORKING AREA PUSKESMAS BATU AJI
}

\author{
Junita Henriette $^{1}$, Brain Gantoro ${ }^{2}$ \\ junitahenriette@univbatam.ac.id ${ }^{1}$, briangantoro@univbatam.ac.id ${ }^{2}$ \\ Professional Doctor Study Program, Faculty of Medicine, Batam University ${ }^{1}$ \\ 2Medical Study Program, Faculty of Medicine, University of Batam ${ }^{2}$ \\ Jl.Abulyatama No 05
}

\begin{abstract}
Background : Intra Uterine Device (IUD) is an effective way to regulate birth and terminate pregnancy. To choose a contraceptive to use, a woman (wife) certainly really needs the opinion and support of her partner (husband). This study aims to determine the relationship between husband's support and the use of IUD contraceptives. This research.
\end{abstract}

Method :The research method is analytical survey with cross sectional approach. Conducted at the Batu Aji puskesmas for 6 months, the population in this study were all family planning acceptors in the working area of the Batu Aji Community Health Center as many as 19,479 family planning acceptors. With a sample size of 99 people, sampling using purposive sample with research instruments using a questionnaire and analyzed using chi Square.

Result : The results showed that most respondents received support from their husbands as many as 82 respondents $(82.8 \%)$, mothers who received support from their husbands and used an IUD as many as 31 respondents $(31.3 \%)$, and those who did not use an IUD were 51 respondents $(51.5 \%)$. From the results of the Chi-Square calculation, the p-value is 0.001 . The

conclusion : there is a relationship between husband's support and the use of IUD contraceptives for family planning acceptors in the working area of the Puskesms Batu Aji

Keywords: Husband's Support, IUD

\section{PRELIMINARY}

Population growth continues to occur in large numbers because efforts to reduce the Population Growth Rate (LPP) and Total Fertility Rate (TFR) have not achieved the expected results. According to the 2015 World Population data sheet, Indonesia is the 5th country in the world with the largest population, namely 255 million. Among ASEAN countries, Indonesia is the largest population. The results of the 2012 Indonesian Demographic and Health Survey (IDHS) found that the total TFR (Total Fertility Rate) of 2.6 per woman has not decreased in the last 10 years since the 2002- 2003

In overcoming population problems, the Indonesian nation has held a Family Planning (KB) program. To achieve this goal, the management of the national family planning program is directed at the form of targets, namely direct targets in the form of couples of reproductive age (PUS), couples of reproductive age 20 - 35 years and indirect targets through organizations, social institutions, government and private agencies, community leaders. (Hartanto, 2004)

The family planning program is not only aimed at controlling the rate of population growth, but also to meet community demand for quality family planning and reproductive health (KR) services, reduce maternal mortality (MMR) and infant mortality rates (IMR) and overcome reproductive health problems to establish quality small family (Yuhedi and Kurniawati, 2013)

Contraception is an effort to prevent pregnancy, these efforts can be temporary or permanent. Contraceptives that have high effectiveness and are non-hormonal contraceptives include the IUD. The 
intrauterine device (IUD) is a form of contraception that does not contain hormones.

Intra Uterine Devices (IUD) are an effective, safe, and comfortable contraceptive option for some women. The IUD is a reversible contraceptive method most often used worldwide with the use of approximately 100 million women, mostly in China. The newest generation of IUDs are more than $99 \%$ effective in preventing pregnancy for one year or more (Glacier and Gebbie, 2012). The advantage of this IUD is that apart from being more effective, it does not affect the quality in the volume of breastmilk for breastfeeding mothers, the complication is not too severe, and the restoration of fertility after contraceptive removal is good, safe, easy to use, because you don't have to remember the injection schedule or take birth control pills (Saifudin, 2006)

The long-term contraceptive method (MKJP) is the most effective contraceptive method. When viewed from the data, there is a tendency for non-MKJP contraceptive use patterns, where from $57 \%$ the contraceptive prevalence rate (CPR) of $43.7 \%$ uses nonMKJP and $10.6 \%$ uses MJKP. The pattern of using MKJP tended to decrease $18.7 \%$ in 1991 to $10.6 \%$ in 2012 . The high use of non-MKJP also occurred in new family planning acceptors, namely $82.48 \%$, while those who used MKJP were only $17.52 \%$ (SDKI, 2012)

Husband's support is one of the socio-cultural variables that greatly influences the use of contraceptives for women as wives in particular and within the family in general (Depkes, 2014). One of the indirect ways of male participation is by supporting his wife in family planning. If it is agreed that the wife will have family planning, then the husband's role is to provide support and freedom to the wife to use contraception or the family planning method that will be used (Ermawan, 2012). Based on the research of Bernadus et al (2013), it was found that husband's support had a significant relationship with the choice of IUD at Jailolo Health Center.

The low use of long-term contraceptive methods or Intra-uterine Device (IUD) can be caused by several factors such as: participants' ignorance of the advantages of long-term contraceptive methods, quality of $\mathrm{KB}$ services seen in terms of availability of contraceptives and availability of trained personnel and technical medical abilities of health service workers, long-term contraceptive method service costs are expensive, there are obstacles to support from the husband in using long-term contraceptive methods, and the value arises from attitudes based on beliefs and norms in society (BKKBN, 2006 in Ratih, 2015).

A preliminary study conducted on 10 family planning acceptors, of whom 2 PUS (20\%) chose IUD contraception, 8 PUS (80\%) did not choose IUD contraception. It is known that there are very few IUD choices because they are still afraid of the IUD because the IUD is inserted through the birth canal. So that the majority have the opinion that the use of hormonal contraceptives (pills, injections) is better than non-hormonal contraceptives (IUD). This is because the husband's knowledge of IUD contraception is lacking, and the husband's lack of support. Thus causing the choice of IUD contraception to decrease

Based on the background description above, the researcher is interested in conducting research on "The Relationship between Husband Support and the Use of Intra Uterine Device (IUD) for Family Planning Acceptors"

\section{RESEARCH PURPOSES}

This research was conducted to determine the relationship between husband's support and the use of intrauterine device (IUD) contraceptives in the working area of Puskesmas Batu Aji, Batam City.

\section{RESEARCH METHODS}

This research. The research method is analytical survey with cross sectional approach. Conducted at the Batu Aji puskesmas for 6 months, the population in this study were all family planning acceptors in the working area of the Batu Aji Community Health Center as many as 19,479 family planning acceptors. With a sample size of 99 people, sampling using purposive sample with research instruments using a questionnaire and analyzed using Chi Square

\section{RESEARCH RESULT}

From the research results, it was found that most of the respondents received support from their husbands as many as 82 respondents $(82.8 \%)$, and 17 respondents did not receive support from their husbands (17.2\%).

The results showed that 31 respondents $(31.3 \%)$ used the IUD, while 68 respondents $(68.7 \%)$ did not use the IUD. 
Based on the results of the analysis between husband's support and the use of the IUD, it can be seen from the results of the study with a total of 99 respondents, it was found that 31 respondents $(31.3 \%)$ received the support of their husbands and used the IUD, and those who did not use the IUD were 51 respondents $(51.5 \%) . \%$ ), while respondents who did not get the support of their husbands who used the IUD were not respondents $(0.0 \%)$, while those who did not use the IUD were 17 respondents $(17.2 \%)$. From the results of the Chi-Square calculation, the $p$-value is 0.001 because the $p$ value $<0.05$ means that Ho is rejected, it can be concluded that there is a relationship between the level of knowledge and the use of IUD contraceptives.

\section{DISCUSSION}

\section{Husband's Support}

From the research results, it can be seen that most of the respondents received support from their husbands as many as 82 respondents $(82.8 \%)$, and 17 respondents did not receive support from their husbands (17.2\%).

Husband's support according to Friedman (2010) in Bela, (2016), is one of the reinforcing factors that can influence someone's behavior. Meanwhile, husband's support in family planning is a tangible form of men's care and responsibility.

Husband's support can be translated as an understanding attitude that is shown in the form of positive cooperation, helping to complete household chores, and providing moral and emotional support to his wife's career or job.

The results of this study are in line with Sri's research (2014) entitled the relationship between husband's support and maternal interest in using IUD contraceptives in gas, it is known that husband's support is in the supportive category, namely 45 people $(50.6 \%)$ are slightly higher than those who do not provide yes support, 44 people $(49,4 \%)$.

Various supports that can be provided by their partners are in the form of emotional support, appreciation support, information support, and assessment support, Setiadi (2008). Spouse support can be translated as attitudes attentiveness which is shown in the form of positive cooperation, helping to complete household chores, planning family planning and providing moral and emotional support to the career or work of the couple Jacinta (2007). Support is the involvement provided by Jacinta. family and friends to clients to organize and care for themselves (Indanah, 2010). Support can be in the form of relationships between individuals in a positive attitude, affirmation, and assistance (Safarino, 2006). Support as a behavior that can foster a sense of comfort and individuals feel valued, respected and loved. This is in accordance with research conducted by (Auliyah, 2015) which concluded that husband's support will influence a wife's decision making in choosing contraception.

Based on the results of the study, it can be concluded that most of the respondents received good support from their husbands. In making decisions about using contraceptives, the husband's support includes obtaining information, choosing a contraceptive device, delivering to health services and financing the installation of contraceptives. The better the support provided by the husband, the better the support provided by the husband, the better the decision making is in accordance with the wishes of the husband and wife, on the other hand, if the husband's support is lacking, the husband's dissatisfaction will arise. in the use of contraceptives

\section{Use of the IUD}

From the results of the study, it was found that 31 respondents (31.3\%) used the IUD, while 68 respondents $(68.7 \%)$ did not use the IUD.

The choice of contraception is a decision making for the use of contraceptives (Hartanto, 2010). Contraceptives used to prevent pregnancy.

The fear of IUD contraception could also be the cause of the respondents' lack of interest in choosing the IUD KB. This fear can be in the form of fear of the side effects of the IUD, fear of the insertion process, and fear of the disadvantages of using the IUD. In addition, fear can also occur as a result of other individual experiences experiencing pain and bleeding / shooting that occurs after IUD insertion. Usually disappears within 1-2 days (Prawirohardjo, 2011)

Community culture is one of the contributing factors, the dominance of the husband is very high in the choice of IUD contraception. This situation can affect a woman's interest in using the IUD as a contraceptive device 


\section{Coralation Husband's Support with IUD Use}

Based on the results of the analysis between husband's support and the use of the IUD, it can be seen from the results of the study with a total of 99 respondents, it was found that 31 respondents $(31.3 \%)$ received the support of their husbands and used the IUD, and those who did not use the IUD were 51 respondents $(51.5 \%) . \%$ ), while respondents who did not get the support of their husbands who used the IUD were not respondents $(0.0 \%)$, while those who did not use the IUD were 17 respondents (17.2\%). From the results of the Chi-Square calculation, the p-value is 0.001 .

Similar research conducted by Sri Sulastri with the title of husband's relationship with mother's interest in the choice of IUD contraceptive, the results of the research of respondents who received support were slightly higher than those who did not get support, namely $50.6 \%$ and most of the respondents had low interest $76.4 \%$

. The results of statistical tests with the ChiSquare test obtained a $p$ value of $(0.006)<\alpha$ (0.05). Based on the results of statistical tests that there is a significant relationship between husband's support and mother's interest in choosing IUD contraceptives. The results of this study are in accordance with Notoatmodjo's (2012) theory, which states that the husband's support in determining the choice of contraceptive is needed by a wife, because with support from a husband to a wife will be more comfortable in making decisions and in using contraceptives

This research is also in line with research from Darrell Fernandodan Rachmat in 2015 with the title Husband's Support is a Main Factor Associated with Contraceptive Practices, the result is that husband's support is the main factor related to contraceptive practice. The choice of contraceptive method must be adjusted according to the patient's ability and desire to prevent failure in family planning. According to Setiadi (2008), husband's support is the nature of interactions that take place in various social relationships as evaluated by individuals, namely wives. Social support as verbal information, suggestions, real help or behavior provided by the husband with the subject in his social environment or in the form of presence and things that can provide emotional benefits or affect the behavior of the recipient. In this case, people who feel they have social support feel emotionally relieved to be noticed, get suggestions or pleasant impressions on themselves

Husband's support can be interpreted as an understanding attitude which is shown in the form of positive cooperation, providing emotional support for his wife's work. The husband is the main person and first gives encouragement to the wife about the use of contraceptives, especially the IUD. Husband's support in reproductive health, especially family planning or family planning is very influential in the choice of contraceptives, as it is known that in Indonesia the husband's decision to allow his wife is an important guideline for wives who using contraceptives. If the husband does not allow or give consent to use contraceptives, the husband makes the decision to use contraception and the husband's willingness to use contraceptives in the uterus.

This result is also supported by the results of research conducted by Ismi (2017) with the title of the relationship between husband's support and the choice of IUD contraception at Puskesmas Tempel 1 Sleman Jogjakarta, the results of which are the closeness of the relationship between husband's support and the choice of IUD contraception based on tests with a contingency coefficient. that $\mathrm{C}=0.696$ so it can be concluded that there is a relationship between husband's support and the choice of IUD contraception at Puskesmas Tempel 1 Yogyakarta in 2017 with a significant statistical test result (Ha accepted, Ho rejected), p-value $0.000<0.05$

According to the researcher's analysis, it can be concluded that the husband's support affects participation in IUD family planning. The husband's role in the family is very dominant and holds the power in decision making whether the wife will use contraception or not, because the husband is seen as the protector, the breadwinner in the household and the decision maker.

The decisions taken will be based on deliberations with husbands and wives, so the higher the husband's support for the IUD KB, the higher the participation of respondents in using the IUD, for this it is very important to support the wife in making decisions, especially in participating in family planning. 


\section{CONCLUSION}

From the results obtained in a study with 99 respondents, the following conclusions can be drawn:

1. Husband's support given to family planning acceptors in the work area of the Batu Aji Community Health Center, 82 respondents $(82.8 \%)$ supported the use of an IUD, 17 Respondents (17.2\%) did not support the use of an IUD.

2. The use of IUDs in the work area of the Batu Aji Community Health Center, where those who used the IUD were 31 respondents (31.3\%) and those who did not use were 68 respondents $(68.7 \%)$.

3. significant relationships between husband's support and the use of IUDs in the working area of the Batu Aji Community Health Center. From the results of the Chi-Square calculation, the $\mathrm{p}$-value is 0.001 because the $\mathrm{p}$ value is $<0.05$

\section{SUGGESTION}

The suggestions that can be given are as follows:

\section{For Respondents}

It is hoped that family planning acceptors can increase their knowledge from various sources of information about IUDs and can choose contraceptives that have high effectiveness and low failure rates, especially for mothers who already have 2 children.

2. For Further Researchers

It is hoped that the next researchers will conduct research with other variables related to the use of IUDs on family planning actors besides the knowledge and support of their husbands.

3. For Health Institutions
It is hoped that health institutions, especially health workers in the field of family planning services, can always provide counseling, guidance and advice to family planning acceptors so that they have better knowledge about IUD contraceptives.

4. For Educational Institutions

Can be a source of additional information for students, especially in the health sector in conducting further research related to the title. continued with more complex methods and variables about Intra Uterine Device (IUD) contraception

\section{DAFTAR PUSTAKA}

Astuti, sumiyati. 2013. Hubungan tingkat pengetahuan dan sikap masyarakat terhadap upaya pencegahan penyakit tuberkolosis RW 04 kelurahan lagoa. Jakarta utara: Universitas Islam Negeri Syarifhidayatullah

Amaris, susanto bela novita. 2013. Hubungan Antara Dukungan Suami Terhadap Istri Dengan Keputusan Pengunaan Alat Kontrasepsi Di Wilayah Kerja Puskesmas Ngemplak Boyolali, Surakarta : Universitas Muhammadiyah Surakarta

Anjani, A. D. (2017). PENGARUH PEMBERIAN INFORMASI TERHADAP PENGETAHUAN IBU MULTIPARITAS TENTANG IMPLAN. Jurnal Kebidanan Malahayati, 3(1).

BKKBN, 2015 Laporan Kinerja Instansi Pemerintah 2015. Batam

BKKBN, 2015 Laporan Kinerja Instansi Pemerintah 2015. Batam

Data Dinas Kesehatan. 2016. Data Rekap Pengguna IUD Dikota Batam, Tidak Dipublikasikan

Diah, kuswandari Tika. 2015. Perbedaan Pengetahuan Sebelum Dan Sesudah Pemberian Pendidikan Dengan Metodes Nowball Throwing Tentang Kontrasepsi Hormonal Pada Pasangan Usia 
Suburnon Akseptor Kb Di Pucangan Puskesmas Kartasura Kabupaten Sukoharjo. Surakarta : Universitas Muhammadiyah Surakarta

Dwi, arini ratih. 2015.Hubungan Antara Dukungan Suami Dan Pengetahuan Ibu Dengan Pemilihan Alat Kontrasepsi Intra Uterine Device (IUD) Di Puskesmas Polokarto Kabupaten Sukoharjo. Surakarta :Universitas Muhammadiyah Surakarta

Eka, fitri selfya. 2014. Hubungan Antara Tingkat Pengetahuan Ibu Tentang Kontrasepsi Suntik Dmpa Dengan Kepatuhan Jadwal Penyuntikan Ulang Di Puskesmas Sukaramai. Sumatra Utara : Universitas Sumatera Utara

Fridalni Nova. 2012. Hubungan Tingkat Pengetahuan, Sikap, Dan Dukungan Suami Tentang KB Dengan Keikutsertaan KB Oleh Pasangan Usia Subur (PUS) Di RW III Kelurahan Korong Gadang Wilayah Kerja Puskesmas Kuranji Padang Tahun 2012,

Fafi (2014) Hubungan tingkat pengetahuan tentang HIV/AIDS dengan sikap terhadap pencegahannya pada siswa kelas $x$ dan $x I$ di SMA TAMAN MADYA jetis Jogyakarta. Karya tulis ilmiah tidak di terbitkan. Stikes Aisiyyah Yogyakarta

Hartika, sari noviana. 2016. Hubungan Pengetahuan Ibu Dengan Penggunaan Alat Kontrasepsi IUD DiPuskesmas Payung Rejo Kabupaten Lampung Tengah. Lampung : Universitas Lampung Bandar Lampung

Laporan Puskesmas Baloi Permai Kota Batam (2016).Data Rekap pengguna IUD.Tidak Di publikasikan

Meirani, danti. 2016.Perbedaan Tingkat Pengetahuan Dan Sikap Ibu Hamil Sebelum Dan Sesudah Penyuluhan Mengenai IUD Pascaplasenta. Universitas Diponegoro

Maryatun. (2009). Analisis Faktor-faktor Pada Ibu yang Berpengaruh Terhadap Pemakaian Metode Kontrasepsi IUD di Kabupaten Sukoharjo Gaster. Stikes Aisyiyah Surakarta.
Mardhiah, A., \& Anjani, A. D. (2020). HUBUNGAN PENGGUNAAN KONTRASEPSI HORMONAL DENGAN KEJADIAN KANKER PAYUDARA DI RSUD EMBUNG FATIMAH KOTA BATAM TAHUN 2017. Zona Kebidanan: Program Studi Kebidanan Universitas Batam, 9(2)

Maternity, Dainty; Ratna, DP; Devy, LNA. (2017). Asuhan Kebidanan KomunitasDisesuaikan dengan Rencana Pembelajaran Kebidanan. Penerbit Andi, Yogyakarta

Mufdillah, Kanthi Aryekti. (2016). Dukungan Suami Terhadap Kejadian Drop Out Bagi Akseptor Keluarga Berencana (KB) di Desa dan di Kota di Daerah Istimewa Yogyakarta. Journal Mufdillah, vol. 15 no.1 Januari 2016

NotoatmodjO soekidjo. 2010. Metodologi Penelitian Kesehatan. Jakarta. Rineka Cipta

Nurul Aulia, D., \& Anjani, A. (2019). Hubungan Pengetahuan dan Sikap Ibu Balita dengan Perilaku Keluarga Sadar Gizi (KADARZI). Journal for Quality in Women's Health, 2(1), 36-42. Retrieved from

https://www.jqwh.org/index.php/JQWH /article/view/25

Nurcahyanti, Idam. 2014.Hubungan Dukungan Suami Dalam Pemilihan Metode Kontrasepsi Jangka Panjang Pada Ibu Akseptor Kb Berusia Lebih Dari 35 Tahun Di Desa Sidomukti Kecamatan Bandungan Kabupaten Semarang. Semarang : Sekolah Tinggi Ilmu KesehatanNgudi Waluyo

Nurchayanti, I. (2014). Hubungan dukungan suami dalam pemilihan kontrasepsi jangkapanjang pada ibu akseptor KB berusia lebih dari 35 tahun di Desa Sidomukti Kecamatan Badungan Kabupaten Semarang. Semarang.

Permana, hargi jayanta. 2013.Hubungan Dukungan Suami Dengan Sikap Ibu dalam Pemberian Asi Eksklusif Di Wilayah Kerja Puskesmas Arjasa Kabupaten Jember. Universitas Jember

Pinamangun, Wasti, Dkk, 2018. Hubungan Dukungan Suami dengan Pemilihan 
Jenis Kontrasepsi Intra Uterine Device Pada Wanita Usia Subur di Puskesmas Makalehi Kecamatan Siau Barat.

Prasetyawati, Arsita E, 2011. Ilmu Kesehatan Masyarakat Untuk Kebidanan Holistik. Yogyakarta : Nuha Medika Purnandias, Imani L, dkk, 2016. Hubungan Persepsi Efek Samping IUD, Dukungan Suami Dan KepraktisanIUD Dengan Keikutsertaan Akseptor IUD Di Kelurahan Jatisari Kecamatan Mijen Kota Semarang Tahun 2016. Semarang

Saifudin. 2006. Buku Panduan Praktis Pelayanan Kontrasepsi. Jakarta : Yayasan Bina Pustaka Sarwono Prawirohardjo

Sugiyarningsih, S., \& Anjani, A. D. (2021). HUBUNGAN PENGETAHUAN IBU PASCA SALIN DENGAN PERILAKU IBU PASCA SALIN DALAM KEPESERTAAN KB PASCA SALIN DI PUSKESMAS TEBING TAHUN 2017. Zona Kebidanan:
Program Studi Kebidanan Universitas Batam, 9(1).

Suherdi, fauzan. 2015. Pengetahuan, Sikap dan Perawatan Diri Klien dengan Rematikyang Tinggal di Wilayah Puskesmas Muaro Bodi Kecamatan IVNagari Kabupaten Sijunjung Sumatera Barat. Sumatera Utara : Universitas Sumatera Utara

Wahyu, Kustiantari muliyana. 2015. Hubungan Tingkat Pengetahuan Ibu Tentang Alat Kontrasepsi Dan Dukungan Suami Dengan Pemakaian IUD Pada Akseptor $K b$,Batam : Universitas Batam

Wardani, tanjung wiwi. 2013. Faktor-Faktor Yang Mempengaruhi Rendahnya Minat $\mathrm{Ibu}$ Akseptor $\mathrm{Kb}$ Menggunakan Kontrasepsi Akdr Di Lingkungan IV Kelurahan Asam Kumbang Kecamatan Medan Selayang. Sumatera Utara : UniversitasSumatera Utara 